\title{
Conexões entre a Confederação Operária Brasileira e a Região Norte: militância e imprensa operária no Amazonas e no Pará (1906-1920)
}

\author{
Connections between the Brazilian Workers' Confederation and \\ the Northern region: militancy and workers' press in Amazonas \\ and Pará (1906-1920)
}

\section{Luciano Everton Costa Teles*}

Resumo: Neste artigo busca-se analisar as conexões entre a Confederação Operária Brasileira (COB), considerando também os três Congressos Operários Brasileiros (1906, 1913 e 1920) e a Região Norte do país. Para isso, utilizou-se como fonte principal a imprensa operária, que teve papel primordial como instrumento mediador e de ligação entre as diversas partes do país e do mundo. Ela era animada por militantes que também circulavam por várias regiões do território nacional e que carregavam consigo um cabedal de experiências de organização e luta social. Nesse sentido, os contatos e as conexões construídas socialmente possibilitaram a constituição de um circuito pelo qual as informações sobre o processo organizativo e de luta dos trabalhadores passaram a circular, e permitiram a circulação de análises sociais e, consequentemente, modelos de organização, ação e luta. A COB e os três congressos são efeitos desse processo.

Palavras-chave: Confederação Operária Brasileira; imprensa operária; Região Norte.

Abstract: This article seeks to analyze the connections between the Brazilian Workers' Confederation (COB), also considering the three Brazilian Workers' Congresses (1906, 1913 and 1920), and the North region of the country. For this, the working press was used as the main source, which had a primordial role as a mediating and linking instrument between the

* Doutor em História pela Universidade Federal do Rio Grande do Sul (UFRGS). Professor Adjunto da Universidade do Estado do Amazonas (UEA). E-mail: Icteles@uea.edu.br. ORCID: https://orcid.org/00000001-6569-5606. 
different parts of the country and the world. It was animated by activists who also circulated in various regions of the national territory and who carried with them a wealth of experiences of organization and social struggle. In this sense, socially constructed contacts and connections enabled the constitution of a circuit through which information about the organizational and struggle process of workers began to circulate, and allowed the circulation of social analyzes and, consequently, models of organization, action and fight. The COB and the three Congresses are effects of this process.

Keywords: Brazilian Workers' Confederation; Workers' Press; North Region.

\section{Considerações iniciais}

$\mathbf{N}$ O DECORRER da Primeira República brasileira, os trabalhadores que assumiram um papel de liderança, ${ }^{1}$ sobretudo nos principais centros urbanos do país, com a finalidade de analisar e avaliar a situação social da classe trabalhadora no mundo do trabalho - salário, condições de trabalho, processo organizativo, greves, dentre outros temas - e se posicionar politicamente frente a ela, buscando com isso organizar os trabalhadores em sociedades operárias e construir, a partir desse processo de organização, espaços políticos de intervenção social, objetivando melhorar as condições de vida e trabalho de diferentes categorias numa República que se configurou como excludente, ${ }^{2}$ trataram de viabilizar contatos e conexões entre lideranças localizadas em diversas regiões do país e do mundo. ${ }^{3}$

É inegável que esses contatos e conexões possibilitaram a construção de um circuito por onde as informações sobre o processo organizativo e de luta dos trabalhadores passaram a circular, mas também permitiram a circulação de análises sociais e, consequentemente, modelos de organização, ação e luta. A circulação de ideias foi fundamental para sedimentar o sentimento de luta levado adiante, até mesmo em situações adversas e de perseguições políticas duras, pelos trabalhadores em geral e suas lideranças em particular. Nesse processo, a imprensa operária teve papel primordial, como instrumento mediador e de ligação entre diversas partes do país e do mundo. Somado a isso, temos também a circulação de militantes, que levavam consigo todo o cabedal de experiências de luta social, e, por fim, os congressos

1 Lideranças aqui são entendidas como aqueles militantes que não se restringiam apenas as suas categorias profissionais, atingindo os operários em seu conjunto, mas também por atuarem de forma substancial na produção, sustentação e circulação de uma imprensa, através da qual procuravam difundir suas interpretações sociais e seus projetos de participação política, diferenciando-se dos quadros intermediários (grupo maior que participa ativamente da vida da categoria, integra direções de associações, assina manifestos, porém pouco escreve sobre suas práticas e muito menos produz teorias) e dos militantes de base (os mais numerosos, os que exercem uma militância eventual, em especial em momentos de ascensão dos movimentos). Ver: BATALHA, Cláudio Henrique de Moraes. Vida associativa: por uma nova abordagem da história institucional nos estudos do movimento operário. Anos 90, Porto Alegre, n. 8, p. 93, dez. 1997.

2 FERREIRA, Jorge; DELGADO, Lucília de Almeida Neves. O Brasil republicano. v. 1. O tempo do liberalismo excludente: da Proclamação da República à Revolução de 1930. Rio de Janeiro: Civilização Brasileira, 2003.

3 TELES, Luciano Everton Costa. Construindo redes sociais, projetos de identidade coletiva e espaços políticos: a imprensa operária no Amazonas (1891-1928). 2018. Tese (doutorado em História) - PPGHIST, Departamento de História, Universidade Federal do Rio Grande do Sul, Porto Alegre, 2018. 
operários que intentavam articular o movimento de luta dos trabalhadores a um nível amplo, nacional e internacional. ${ }^{4}$

No Brasil, mesmo antes da Proclamação da República, mas, sobretudo, nos anos iniciais dela, já é possível atestar as conexões e a circulação de informações e ideias por intermédio de redes tecidas pelos militantes e viabilizadas de forma mais intensa pela imprensa operária. A título de ilustração, podemos citar o jornal Tribuna Operária (1891-1894), órgão do Partido Operário do Pará, este filiado ao Partido Operário Socialista Brasileiro, que definiu a sua linha ideológica pró-socialista de acordo com a II Internacional, ${ }^{5}$ ou então mencionar o jornal Gutenberg (1891-1892), órgão do Partido Operário do Amazonas, que trazia em seu bojo informações sobre o movimento operário de diversas partes do Brasil. ${ }^{6}$ Sem falar sobre a tentativa frustrada, em 1892, de comemoração do $1^{\circ}$ de Maio no Pará, que não ocorreu em virtude de uma ação repressiva truculenta da polícia do governador Lauro Sodré. ${ }^{7}$

Desde muito cedo, tais redes de circulação de conteúdos e ideias de crítica e de ações sociais se colocaram como uma realidade e preocuparam as elites políticas e econômicas nacionais e locais da época, que agiram de diversas formas para frear e reprimir tais movimentos e ações dos trabalhadores. Estes, por meio de suas lideranças, reagiram buscando articular uma luta de alcance maior, mais ampla, e os congressos operários devem ser entendidos como uma resposta nesse sentido.

O presente artigo tem como objetivo central analisar as conexões entre a Confederação Operária Brasileira ( $\mathrm{COB}$ ), considerando também os três Congressos Operários Brasileiros (1906, 1913 e 1920), e a Região Norte do país. Como já disseram Maria de Nazaré Sarges e Wilson Brito Nascimento, Manaus e Belém se colocam como "duas irmãs", ${ }^{8}$ pois ambas se transformaram em centros comerciais, ampliaram seus mercados de trabalho e passaram a se integrar num circuito internacional de circulação de bens, pessoas e capitais proporcionados pelo avanço da economia da borracha. Nesse sentido, vamos buscar tratar dessas conexões considerando as duas cidades do norte do país.

4 PETERSEN, Sílvia Regina Ferraz. Cruzando fronteiras: as pesquisas regionais e a história operária brasileira. Anos 90, Porto Alegre, n. 3, p. 129-153, jun. 1995.

5 SALLES, Vicente. Marxismo, socialismo e os militantes excluídos. Belém: Paka-tatu, 2001. p. 50.

6 PINHEIRO, Luís Balkar Sá Peixoto Pinheiro; PINHEIRO, Maria Luiza Ugarte (org.). Imprensa Operária no Amazonas. v. 1. Transcrições e fac-símiles. Manaus: EDUA, 2004.

7 Os preparativos e a organização para a comemoração da data foram realizados e noticiados no jornal Tribuna Operária. Não obstante, como ressalta Salles, na madrugada do dia 29 para 30 de abril de 1892 , ocorreu "o assalto e empastelamento do jornal operário pela polícia" do Pará, com prisões e espancamentos dos responsáveis pela circulação do jornal e demais operários que lá se encontravam. Segundo Salles, tal acontecimento "está vastamente documentado na imprensa da época, principalmente a oposicionista". SALLES, op. cit., p. 51.

8 SARGES, Maria de Nazaré; NASCIMENTO, Wilson Brito. O Pará e o Amazonas são irmãos: a Amazônia unida na crise da borracha e a imigração estrangeira. In: SOUSA, Fernando de; MARTINS, Ismênia; MENEZES, Lená Medeiros de; MATOS, Maria Izilda; SARGES, Maria Nazaré; SILVA, Susana Serpa (org.). Um passaporte para a terra prometida. $1^{\text {a }}$ ed., v. 1, p. 273-286. Porto: Fronteira do Caos, 2011. 


\section{Tércio Miranda e Antônio Carvalho: lideranças anarquistas no norte do país}

A CIRCULAÇÃo de lideranças operárias por diversas regiões do globo ocorreu como resultado de pressões/perseguições políticas, oportunidades de trabalho ou deportações. ${ }^{9}$ De qualquer forma, esses deslocamentos contribuíram sobremaneira para a difusão de ideias, viabilizada pelas próprias lideranças, e pelo estabelecimento de contatos e vínculos por onde elas passavam, numa costura social que se mantinha através das correspondências e da própria imprensa operária. Além do que, como já foi apontado anteriormente, traziam consigo uma experiência prévia no processo de organização e luta dos trabalhadores.

Quando Tércio Miranda e, possivelmente, Antônio Carvalho chegaram à Amazônia, o primeiro no Amazonas e o segundo no Pará, encontraram, respectivamente em Manaus e em Belém, duas capitais já transformadas pela economia da borracha, dois centros comerciais com uma intensa circulação de pessoas e capitais, mas também com um mercado de trabalho modificado e ampliado. Tércio Miranda foi incorporado, num primeiro momento, ao Jornal do Comércio ${ }^{10}$ como trabalhador responsável pelas fotogravuras. ${ }^{11}$ Antônio Carvalho, em Belém, embora sendo gráfico, montou um pequeno comércio na área central da cidade. ${ }^{12}$ Ambos, já estabelecidos em termos de trabalho, passaram a propagar o ideário libertário na Amazônia.

Tércio Miranda nasceu em solo português. Em Portugal, entrou em contato com o anarquismo e em seu país passou a defender e a difundir as ideias libertárias, especialmente na perspectiva do sindicalismo revolucionário. Entre os anos de 1908 e 1912, na cidade do Porto, por exemplo, o nosso personagem participou do Grupo Aurora Social, que se vinculava ao jornal Aurora, de caráter anarquista. Ele marcou presença também na Liga D'Educação Nova, especialmente no ano de 1912. ${ }^{13}$

Por outro lado, Antônio Carvalho, da mesma forma que Tércio Miranda, era português e gráfico. Certamente trabalhou em oficinas de jornais no seu país de origem e, dessa forma, entrou em contato com o anarquismo e o difundiu através das palavras impressas. Cabe salientar que vários grupos sociais participaram do processo de implantação da república em

9 PETERSEN, op. cit.

10 Jornal da chamada grande imprensa que passou a circular no cenário urbano de Manaus em janeiro de 1904. Tornou-se centenário. Circula até hoje. Sobre o referido jornal, consultar: SOUZA, Leno José Barata. Cultura impressa no Amazonas e a trajetória de um jornal centenário. Tempos Históricos, v. 14, p. 106-133, $2^{\circ}$ sem. 2010.

11 BARROS, Cláudia Amélia. As peripécias de um anarquista português nas terras amazônicas: a trajetória militante de Tércio Miranda através das folhas operárias do Lucta Social e União - 1914. In: QUEIRÓS, César Augusto Bubolz; CAMPOS, Gláucia de Almeida. Trabalho e trabalhadores na Amazônia: caminhos e possibilidades para uma história em construção. Manaus: EDUA, 2017. p. 142.

12 FONTES, Edilza. Preferem-se português(as): trabalho, cultura e movimento social Belém do Pará. 2002. Tese (doutorado em História) - Instituto de Filosofia e Ciências Humanas, Universidade Estadual de Campinas, São Paulo, 2002. p. 247.

13 TELES, Luciano Everton Costa. A Lucta Social e a existência de uma rede anarquista regional: Tércio Miranda/ AM e Antônio Carvalho/PA (1914). Revista Piauiense de História Social e do Trabalho, Parnaíba, ano 2 , n. 2, p. 10, jan./jul. 2016. 
Portugal no ano de 1910, dentre eles estavam presentes os trabalhadores e suas lideranças que, ao lado dos republicanos, lutaram para derrubar a monarquia.

Os trabalhadores, de uma forma geral, e os anarquistas, em particular, fizeram uma aliança com os republicanos porque estes, em oposição à monarquia, construíram uma plataforma política que incorporava questões sociais e políticas muito próximas às do socialismo, o que acabou dividindo o operariado português entre as promessas republicanas e as demandas da CGT francesa. ${ }^{14}$ Com a República sendo uma realidade, ela foi se configurando num formato burguês, postergando a participação e também os anseios e projetos políticos dos trabalhadores. Nesse contexto, o projeto anarquista foi colocado de lado e alguns de seus defensores foram perseguidos e presos em Portugal. ${ }^{15}$

Esse clima de perseguição e prisão foi produto das respostas dadas pelos governantes republicanos que manifestaram "a sua profunda hostilidade ao movimento autônomo dos trabalhadores". Desse modo, no ano de 1912, com apoio militar, realizou-se um forte movimento de "caça às bruxas", tornando proibida a propaganda libertária, além de, como foi dito, perseguir e prender algumas lideranças anarquistas. ${ }^{16}$ Soma-se a isso os problemas estruturais presentes na região portuguesa, como, por exemplo, as "altas taxas de fecundidade, predomínio de um sistema de pequena propriedade, heranças com partilhas restritas e redes de relações sociais fortemente estruturadas". ${ }^{17}$ Certamente que Tércio Miranda e Antônio Carvalho, como militantes anarquistas, observando tanto os problemas estruturais quanto a tensão social que se instalou no país no raiar republicano - com perseguições e prisões -, acabaram resolvendo deixar Portugal em direção ao Brasil.

O que se pode aferir de fato é que, dentre as principais correntes migratórias da Europa para o Brasil, a portuguesa foi a mais significativa numericamente, em especial por ter sido a mais longa e duradoura, estendendo-se do início do século XIX até a metade do século XX. O Brasil não foi o único país de destino, entretanto foi o que mais atraiu os portugueses, em grande medida pelo idioma comum, vínculos históricos e oportunidades econômicas, "além de complexas e duradouras relações econômicas e comerciais e uma comunidade local de negociantes dominada por portugueses". ${ }^{18}$ Tal situação aparece expressa no gráfico abaixo:

14 Entre os mais radicais, incluindo-se aí o movimento libertário, a CGT francesa foi uma referência, fonte de energia para essas lideranças que se inspiraram nela e trocaram experiências, por meio de correspondências, visitas e participação em congressos. Isto fica evidente com a visita de Elisée Réclus ao Porto em abril de 1886. Ver: MESQUITA, Antônio Pedro. O pensamento libertário e anarquista. In: O pensamento político português no século XX. Uma síntese histórico-crítica. Lisboa: Imprensa Nacional - Casa da Moeda, 2006. p. 523.

15 PEREIRA, Joana Dias. Sindicalismo revolucionário em Portugal. Revista Mundos do Trabalho, v. 1, n. 2, p. 201-202, 2009

16 Ibidem, p. 203.

17 KLEIN, Herbert. A integração social e econômica dos imigrantes portugueses no fim do século XIX e século XX. Revista Brasileira de Estudos de População, São Paulo, v. 6, n. 2, p. 18, jul./dez. 1989.

18 KLEIN, op. cit., p. 17. 


\section{Gráfico 1 - Total de emigrantes saindo de Portugal e imigrantes portugueses entrando} no Brasil (1855-1972)

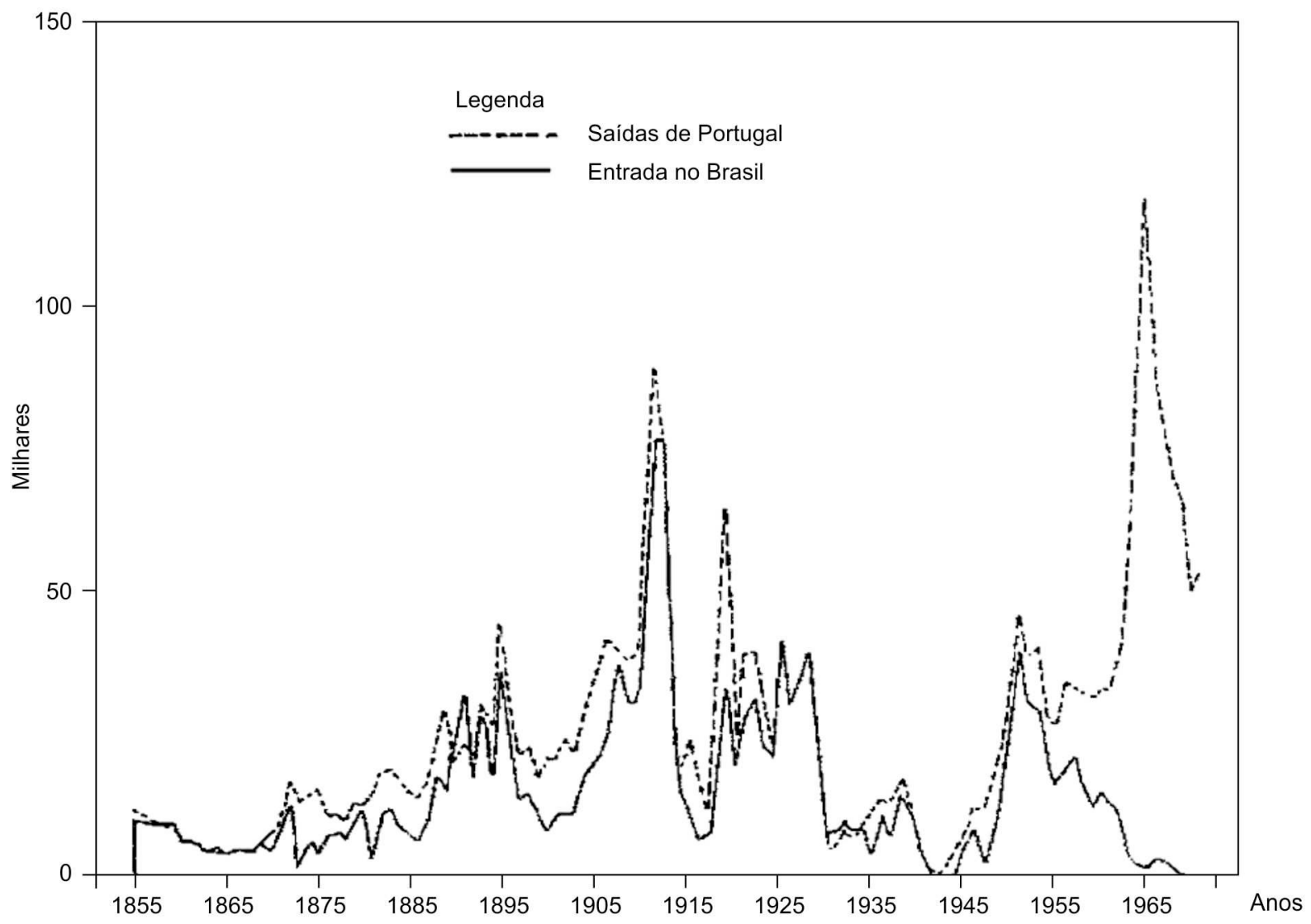

Fonte: KLEIN, op. cit., p. 18.

Tércio Miranda e, ao que tudo indica, Antônio Carvalho chegaram à Amazônia por volta de 1912/13 e encontraram um terreno fértil para plantar a semente do sindicalismo revolucionário.

\section{O Norte como centro comercial da borracha: Manaus e Belém}

No INícıo da década de 1910, tanto Manaus quanto Belém já tinham experimentado um conjunto de transformações urbanas, sociais e culturais promovido pela extração e exportação do látex, que se iniciou em meados do século XIX e se intensificou nas décadas finais deste século e décadas iniciais do século XX. Conforme ressalta Singer:

Conhecida e utilizada pelos indígenas da Amazônia, a hevea torna-se produto comercial de crescente importância após a descoberta da vulcanização da borracha, em 1840. Neste período praticamente toda a borracha era extraída na área amazônica, em território brasileiro ou de países limítrofes, sendo comercializada nos portos de Manaus e Belém. (...) a borracha ganha (...) destaque em nossa pauta de exportação a partir de 1851-60, ocupando o terceiro lugar nela em 1881-90 e o segundo a partir de 1891 até o fim da Primeira Guerra Mundial. A demanda da borracha nos países industrializados 
crescia fortemente, devido à utilização da mesma na fabricação de pneus de veículos: de bicicleta primeiro, de automóveis depois. ${ }^{19}$

Uma vez instalada a demanda externa pela borracha amazônica, a Região Norte se organizou social e economicamente com a finalidade de produzir e escoar a produção da goma elástica. Nesse sentido, as elites extrativistas e comerciais buscaram abrir novos seringais para a extração do látex, interligando-os às duas capitais amazônicas pelas vias fluviais através de barcos a vapor com rotas estabelecidas, procurando com isso atender às demandas impulsionadas internacionalmente. Implantaram-se, como fruto desse processo, uma rede de comercialização do produto e uma infraestrutura necessária para a produção e o escoamento da tão desejada matéria-prima.

Com isso, a Amazônia passou a se integrar ao mercado mundial no decorrer do século XIX, consolidando tal integração a partir das suas três últimas décadas. Localizados na Amazônia, com a expansão da borracha e o consequente avanço das atividades econômicas que ancoravam a produção e o escoamento desse produto, tanto o Pará quanto o Amazonas ${ }^{20}$ sofreram intervenções urbanas que impactaram de forma significativa os estados e suas capitais. Urbanizaram-se e embelezaram-se, ${ }^{21}$ num processo cheio de contradições, conflitos, exclusão social e resistências. ${ }^{22}$

Com efeito, as duas "irmãs" do Norte do país se tornaram centros comerciais e, como tais, viram expandir diversas atividades econômicas em seus espaços urbanos. Neles, o capital inglês passou a atuar na expansão, no controle e na administração dos serviços urbanos, da mesma forma que ocorreu uma significativa ampliação da praça comercial. Em outros termos, as casas comerciais se expandiram e amplificaram a oferta de produtos nacionais e importados e de serviços (hotéis, restaurantes, botequins etc.), assim como também se expandiram as fábricas - de roupas, cigarros, sabão, cerveja, gelo e outras - e o aparato burocrático dos estados. ${ }^{23}$

Essas transformações permitiram igualmente consolidar a imprensa, sobretudo pelas mudanças estruturais ocorridas - urbanização, industrialização, ampliação do mercado de trabalho, imigração, desenvolvimento tecnológico dos impressos etc. - e pelo avanço da cultura letrada, que ultrapassou o restrito círculo das elites tradicionais (alta burocracia, grandes

19 SINGER, Paul. O Brasil no contexto do capitalismo internacional (1889-1930). In: FAUSTO, Boris (org.). História Geral da Civilização Brasileira. v. III. O Brasil Republicano (1889-1930). São Paulo, Civilização Brasileira, 1997. p. 360-361.

20 Não somente o Amazonas. O Pará passou por um processo similar, em especial sua capital Belém. Ver, por exemplo: SARGES, Maria de Nazaré. Belém: riquezas produzindo a belle époque (1870-1912). $2^{a}$ ed. Belém: Paka-Tatu, 2002.

21 DIAS, Ednéa Mascarenhas. A ilusão do fausto: Manaus, 1890-1920. Manaus: Editora Valer, 1999. COELHO, Geraldo Mártires. Na Belém da belle époque da borracha (1890-1910): dirigindo olhares. Escritos, Fundação Casa de Rui Barbosa, Rio de Janeiro, v. 5, p. 141-168, 2011.

22 COSTA, Francisca Deusa Sena da. Quando viver ameaça a ordem urbana: cotidiano de trabalhadores em Manaus, 1915-1925. 2000. Dissertação (mestrado em História) - IFCH/ Pontifícia Universidade Católica, São Paulo, 2000. LACERDA, Franciane Gama; SARGES, Maria de Nazaré. De Herodes para Pilatos: violência e poder na Belém da virada do século XIX para o XX. Projeto História, São Paulo, n. 38, p. 165-182, jun. 2009.

23 PINHEIRO, Maria Luiza Ugarte. Vivências urbanas: o cotidiano de trabalhadores na contramão dos processos de modernização em Manaus. Fronteiras do Tempo, Manaus, v. 1, n. 2, p. 1-15, dez. 2011. 
comerciantes e seringalistas) e englobou os setores médios urbanos (advogados, médicos, professores, funcionários públicos e outros) e os trabalhadores qualificados (especialmente gráficos e caixeiros), que ganharam corpo com esse conjunto de transformações das capitais, potencializando a presença desses "novos grupos" na produção, distribuição e consumo de impressos. ${ }^{24}$

É justamente nesse cenário urbano amazônico que Tércio Miranda, em Manaus, e Antônio Carvalho, no Pará, agiram na propaganda do sindicalismo revolucionário, disputando com lideranças operárias reformistas e colaboracionistas ${ }^{25}$ a condução do movimento operário na Amazônia e enfrentando toda sorte de pressões e perseguições políticas empreendidas pelas elites locais.

\section{A COB e a Região Norte: Manaus e Belém}

Em ManAus, Tércio Miranda entrou em contato com o mundo do trabalho local, primeiramente compartilhando do universo dos gráficos e, a partir daí, certamente observando e conversando com os trabalhadores da região. Nesse seu novo contexto, passou a analisar e a situar a sua nova realidade como um terreno fértil para as ideias de crítica social e, consequentemente, para a propagação do ideário libertário.

Em Belém, Antônio Carvalho montou uma quitanda para sobreviver. Não obstante, as pessoas que para ela se deslocavam, com o objetivo de comprar algum produto, geralmente ali paravam e começavam a conversar, de modo que a quitanda passou a se caracterizar como um espaço de convivência social, onde inclusive os trabalhadores discutiam os seus problemas e escutavam as análises e soluções propostas por Antônio Carvalho. ${ }^{26}$

Embora por meios diferentes, como é possível observar, Tércio Miranda e Antônio Carvalho, através das suas experiências na luta anarquista em Portugal e do contato e conversas com as lideranças e os trabalhadores locais, que possibilitaram uma apropriação dos problemas, das expectativas e das possibilidades de mobilização e ação, iniciaram a difusão das ideias do sindicalismo revolucionário na Amazônia, tratando de articular as diferentes categorias profissionais existentes num processo organizativo para a luta revolucionária.

Tércio Miranda se tornou delegado da COB na Região Norte, em 1913, e Antônio Carvalho participou do $3^{\circ}$ Congresso Operário Brasileiro, em 1920. Nesse sentido, quais foram os impactos da $\mathrm{COB}$ e do $3^{\circ}$ Congresso na Região Norte do país?

24 PINHEIRO, Maria Luiza Ugarte. Folhas do Norte: letramento e periodismo no Amazonas (1880-1920). 2001. Tese (doutorado em História) - Pontifícia Universidade Católica, São Paulo, 2001.

25 Os socialistas, através da organização dos trabalhadores e da formação de partidos políticos, buscavam a transformação da estrutura social em sua totalidade a longo prazo e, nesse processo, consoante o contexto e o embate entre os grupos, notadamente aqueles ligados ao Estado, tenderam a tomar posições reformistas. Por outro lado, os colaboracionistas não visavam à transformação da estrutura social. Em geral, estavam próximos e apoiavam constantemente setores da elite e do governo, restringindo suas ações a pressões morais. Sobre os socialistas reformistas e colaboracionistas consultar: TELES, op. cit. FONTES, op. cit., p. 247-248. 
O $1^{\circ}$ Congresso Operário Brasileiro aconteceu entre os dias 15 e 20 de abril no Rio de Janeiro, em 1906. Esse encontro por si só já evidenciava um esforço inicial no sentido de se obter uma articulação em nível nacional dos trabalhadores do país. Da mesma forma, já apontava a imprensa como um veículo importante para a defesa e difusão dos conteúdos relacionados ao mundo do trabalho. Esse esforço de articulação nacional se materializou na proposta de criação de uma Confederação Operária Brasileira (COB), que apenas se tornou real em março de 1908, ou seja, quase dois anos depois da realização do $1^{\circ}$ Congresso. ${ }^{27}$

Uma das principais finalidades da COB era "estudar e propagar os meios de emancipação do proletariado e defender em público as reivindicações econômicas em todos os meios de propaganda conhecidos, nomeadamente por meio de um jornal que se intitulará $A$ Voz do Trabalhador". ${ }^{28} \dot{E}$ consenso na literatura sobre a $\mathrm{COB}^{29}$ que esta que foi a primeira central sindical brasileira, nesse primeiro momento (1908-1909), em que pese o desejo de se fazer nacional, acabou se limitando ao Rio de Janeiro, apoiando-se na estrutura da Federação Operária do Rio de Janeiro (FORJ). O seu impresso, A Voz do Trabalhador, contou com colaboradores que residiam na capital da República e que, em geral, produziam informações sobre o movimento operário do Rio de Janeiro, o que resultou em críticas de organizações operárias paulistas, como, por exemplo, a União dos Sindicatos de São Paulo.

As lideranças operárias, envolvidas nesse esforço de criar um organismo de alcance nacional para articular nesse nível o movimento e as reivindicações dos trabalhadores, depararam-se com grandes desafios e dificuldades que se refletiram na periodicidade irregular do seu jornal, mas também na limitação de seu alcance. Talvez por isso, nesse primeiro momento, no norte do país, os impactos da COB não tiveram expressão. A própria COB encerrou as suas atividades em 1909.

Todavia, quando surgiu a oportunidade de retomar a COB e seu órgão de imprensa no $2^{\circ}$ Congresso Operário Brasileiro, que ocorreu entre os dias 8 e 13 de setembro de 1913, na cidade do Rio de Janeiro, os militantes envolvidos e empenhados nesse processo trataram de rastrear formas de superar aquelas limitações de antes e, de certa forma, embora num período curto de tempo, conseguiram retomar de modo regular a produção e distribuição d'A Voz do Trabalhador e também dar à $\mathrm{COB}$, efetivamente, um alcance nacional, o que não se constitui em pouca coisa, sobretudo frente às disputas com socialistas reformistas, colaboracionistas

27 PINHEIRO, Paulo Sérgio; HALL, Michael. A classe operária no Brasil, 1889-1930, documentos. São Paulo: Alfa-Ômega, v. 1, 1979.

28 Ibidem, p. 42.

29 TOLEDO, Edilene. "Para a união do proletariado brasileiro": a Confederação Operária Brasileira, o sindicalismo e a defesa da autonomia dos trabalhadores no Brasil da Primeira República. Perseu, ano 7, n. 10, p. 1131, dez. 2013. MARQUES, João Carlos. A voz do trabalhador: cultura operária e resistência anarquista no Rio de Janeiro (1908-1915). 2013. Dissertação (mestrado em História) - Departamento de História, PPGH, Universidade Estadual de Londrina, Londrina, 2013. OLIVEIRA, Tiago Bernardon de. Anarquismo, sindicatos e revolução no Brasil (1906-1936). 2009. Tese (doutorado em História) - Instituto de História, PPGH Universidade Federal Fluminense, Niterói, 2009. BATALHA, Cláudio. O movimento operário na Primeira República. Rio de Janeiro: Jorge Zahar, 2000. 
e catolicistas e às pressões, perseguições e deportações empreendidas pela elite política e econômica do país. ${ }^{30}$

Nesse segundo momento, os impactos da COB na Região Norte foram fortes e significativos, a ponto de se ter um delegado da confederação na Amazônia. Tércio Miranda, assim que chegou à região e se certificou das condições sociais dos trabalhadores e do espaço existente para plantar a semente do sindicalismo revolucionário, com a experiência legada de Portugal e tecendo redes de contato locais, não hesitou em participar do $2^{\circ}$ Congresso Operário Brasileiro.

Retornou ao Amazonas com o objetivo de pôr em prática as diretrizes elaboradas no âmbito da COB. Uma primeira ação de Tércio Miranda, nesse caminho, foi fundar um jornal operário de orientação sindicalista revolucionária, perspectiva predominante na COB. E fez isso em diálogo com outras lideranças libertárias que participaram do $2^{\circ}$ Congresso Operário Brasileiro, como o conhecido Edgard Leuenroth, que inclusive publicou um artigo chamado de "Nossa Imprensa. A Luta Social" no jornal A Lanterna, o que atesta a existência de contatos e conexões entre eles:

Recebemos, dias atrás, mais um número deste periódico - e com este já são seis os que tivemos sobre a nossa mesa de trabalho - que está sendo publicado em Manaus, no Amazonas.

O seu nome e seu subtítulo - órgão operário-livre - dizem bem claramente ao que veio o nosso baluarte da imprensa revolucionária.

Edita-o um grupo de esforçados companheiros, sendo seu redator responsável o camarada Tércio Miranda.

Está bem feito, trazendo sempre bons artigos doutrinários e de crítica social e notas sobre o movimento operário local.

Oxalá os trabalhadores do Norte prestem o devido apoio à Luta Social para que ela viva anos a fio, difundindo pr'aquelas bandas os ideais redentores.

Caixa postal, 78, Manaus, Amazonas - é seu endereço. ${ }^{31}$

Veja-se que a nota identificou o editor do jornal A Lucta Social, chamando-o de "nosso camarada", o que pode denotar a constituição de um vínculo pessoal entre os militantes atuantes nos dois estados; explicitou os assuntos tratados em suas páginas e desejou vida longa ao periódico coirmão no processo de difusão dos ideais libertários no Amazonas. Além disso, constatou algo que serve como termômetro para se tentar medir a intensidade dessa ligação, qual seja, os seis números do jornal presentes na mesa de trabalho dos editores do A Lanterna. Tal fato é significativo dessa ligação e interação, em especial por indicar uma constância nesse vai e vem de trocas de informações e experiências. Não se deve perder de vista que Edgard Leuenroth e Tércio Miranda, assim como outras lideranças libertárias espalhadas pelo país, estabeleceram ligações e reforçaram as mesmas através dos Congressos Operários, em especial o $2^{\circ}$ Congresso Operário Brasileiro que ocorreu em 1913. Com isso, arrisca-se a assinalar que essas conexões eram fruto, como se disse anteriormente, de articulações

30 BATALHA, op. cit.

31 NOSSA imprensa. A luta social. A Lanterna, São Paulo, ano XIV, n. 270, 19 dez. 1914 
pessoais que se mantinham através dos jornais. Inclui-se aí também a circulação de ativistas, em função da própria atividade de militância.

Um aspecto importante que devemos salientar é que as trocas de ideias e experiências, entre os operários envolvidos com a imprensa ligada ao movimento organizado dos trabalhadores, não se davam exclusivamente em um único sentido, seja partindo de estrangeiros que se deslocaram para o Amazonas, de militantes vindos de outras capitais do país e/ou de jornais direcionados ao mundo do trabalho provenientes de outras cidades; pelo contrário, o exemplo acima demonstra a existência de uma "via de mão dupla", na qual o Amazonas também era um ponto de origem, mostrando uma troca significativa no movimento operário como um todo, como também reforça o trecho abaixo acerca do surgimento de associações de resistência no Amazonas norteadas pelo ideal libertário:

União dos Chauffeurs, Carroceiro Boleeiros - com o fim de patrocinar os direitos das classes indicadas no seu título, foi constituída, em Manaus, Amazonas, no mês de fevereiro passado, uma associação de resistência que, segundo nos informaram, obedecerá a orientação do sindicalismo revolucionário.

A sua sede social está na rua Saldanha Marinho, 2.

À nova organização de combate enviamos a saudação da Lanterna, almejando-lhe farta messe de resultados na luta travada em prol da causa dos trabalhadores. ${ }^{32}$

Depois que Tércio Miranda deu esse primeiro passo, o de fundar o jornal A Lucta Social no Amazonas, passou a organizar os trabalhadores locais em associações e sindicatos, como, por exemplo, o Sindicato dos Trabalhadores Gráficos do Amazonas. Também, como delegado da $\mathrm{COB}$, envidou circular pelos estados e cidades do norte do país, com a finalidade de organizar os trabalhadores para a luta libertária:

Devendo fazer uma viagem de propaganda, por alguns estados do norte do país, na qualidade de delegado especial da C.O.B., declaro, afim de informar as agrupações operárias, que com bastante pesar meu, e por motivos que se relacionam com a minha vida particular, não posso partir já, como informava A Voz do Trabalhador, órgão da mesma C.O.B., no seu último número. ${ }^{33}$

Nesse caso específico, a viagem foi adiada por motivos de saúde. Além dos contatos e conexões com os estados do Rio de Janeiro e de São Paulo, Tércio Miranda manteve um diálogo constante com o Pará, especialmente com Antônio Carvalho. Tal conexão é possível ser vislumbrada no próprio jornal $A$ Lucta Social, que registrou várias informações sobre o referido estado, sobretudo movimentos grevistas. Mas o que estava acontecendo no Pará?

Aqui entra Antônio Carvalho. Como vimos, ele montou uma quitanda e ela se transformou em um espaço de difusão do sindicalismo revolucionário. Alguns militantes ali entravam em contato com Antônio Carvalho, que falava sobre as ideias libertárias e até distribuía artigos, jornais e livros que versavam sobre elas. Não foi à toa que nas greves decorridas em Belém,

32 NO AMAZONAS. A Lanterna. São Paulo, ano XIII, n. 249, 27 jun. 1914.

33 A ORGANIZAÇÃO operária do norte. A Lucta Social, Manaus, ano I, n. 4, 1 set. 1914. 
nos anos de 1913 e 1914 - carroceiros, estivadores, padeiros, sapateiros, operários da construção civil, dentre outros ${ }^{34}$-, ele foi acusado pela polícia de ser o grande articulador e organizador das paredes realizadas, o que resultou em processo de busca e apreensão na sua quitanda e, consequentemente, na sua prisão. ${ }^{35}$

Nos autos de busca e apreensão, que foi compilado por Edilza Fontes, algumas questões demonstram e reforçam as ligações e conexões de Antônio Carvalho com a COB e suas lideranças. Nas palavras dela:

Ele era assinante de $A$ Lanterna, pois o número apreendido tinha seu nome na etiqueta de assinantes. Foi encontrado dentre os papéis apreendidos pela polícia, carta dirigida a ele, enviada pela Luta Social, confirmando assim que havia uma grande articulação de Carvalho com o mundo sindical de Belém e do Brasil, pois havia ofícios da Confederação Operária Brasileira do Rio de Janeiro dirigidos a ele, assim como vários escritos anarquistas indicados no jornal A Lanterna foram apreendidos pela polícia. ${ }^{36}$

Além disso, na esteira dessa busca e apreensão, foram encontrados livros, variados jornais anarquistas de São Paulo (A Terra Livre, La Batáglia e O Proletário), do Rio Grande do Sul (Luta Anarquista e Voz da Estiva), do Ceará (Estudo de Pedagogia) e diversos ofícios da Confederação Operária Brasileira dirigidos a Antônio Carvalho. Também foram apreendidos com ele correspondências de Portugal. ${ }^{37}$ Ou seja, assim como Tércio Miranda, ${ }^{38}$ Antônio Carvalho manteve ampla rede de conteúdos e informações por onde circulavam ideias de crítica social e se difundiam os ideais libertários.

A repressão sobre as lideranças anarquistas no Norte do país era constante. Em Manaus, Tércio Miranda apontava no seu jornal libertário isso que era uma grande preocupação dos militantes:

Em Manaus, as fórmulas de emancipação proletária foram mal compreendidas. Hoje, porém, que eles começam a ser assimilados, como experiência e o bom senso aconselha, parece que começa a perseguição. Não vemos nisso benefício algum para quem persegue, porque é ainda prática, que nos mostra perseguição, como o melhor meio de propaganda.

Foi preso no dia 23 um companheiro nosso, querendo-se-lhe assacar a responsabilidade de um boletim, que aconselhava o povo à revolta, ou levá-lo a indicar os seus colaboradores. ${ }^{39}$

Em que pesem as pressões, perseguições, prisões e deportações, que poderiam atingir (e como atingiram!) esses militantes no norte do país, eles não se afastaram do esforço de pôr em prática as deliberações da $\mathrm{COB}$, tentando torná-las reais no cotidiano de muitos trabalhadores. O próprio Tércio Miranda montou em sua residência a oficina, a redação do jornal $A$ Lucta

34 Sobre as greves das referidas categorias consultar: FONTES, op. cit., p. 246-280.

35 Ibidem, p. 247.

36 Ibidem, p. 248.

37 Ibidem.

38 Sobre a ampla rede social tecida por Tércio Miranda, verificar: TELES, op. cit., p. 71-78 e p. 101-108. TELES, Luciano Everton Costa. Tércio Miranda: uma liderança anarquista na Amazônia (1913-1914). Revista Mundos do Trabalho, v. 9, n. 17, p. 101-119, jan./jul. 2017.

39 PERSEGUIÇÃO. A Lucta Social, Manaus, ano I, n. 4, 1 set. 1914. 
Social e a sede da Associação das Artes Gráficas do Amazonas, bem como a sua escola, com uma pequena biblioteca para ser utilizada pelos seus associados e interessados em geral. Certamente fez o mesmo na sua quitanda Antônio Carvalho.

As grandes linhas de atuação traçadas pela COB no país eram justamente:

Promover a união dos trabalhadores para a defesa de seus interesses morais, materiais, econômicos e profissionais; estreitar laços de solidariedade entre o proletariado organizado, dando maior força e coesão aos seus esforços; estudar e propagar os meios de emancipação do proletariado e defender publicamente as reivindicações econômicas dos trabalhadores, através de todos os meios e especialmente através do jornal $A$ Voz do Trabalhador; reunir e publicar dados estatísticos e informações exatas sobre o movimento operário e as condições de trabalho em todo o país. ${ }^{40}$

Foi o que Antônio Carvalho intentou fazer no Pará. Da mesma forma que este, no Amazonas, Tércio Miranda similarmente tratou de organizar os trabalhadores. Fundou, juntamente com alguns de seus camaradas, ${ }^{41}$ a Federação Operária do Amazonas, filiada à COB, cujos estatutos foram publicados no jornal $A$ Lucta Social. ${ }^{42}$ Tércio Miranda tratou de divulgar a Federação, empenhando-se em submeter o seu estatuto às organizações operárias.

Algumas dessas organizações foram estruturadas na perspectiva do sindicalismo revolucionário pelo próprio Tércio Miranda, como, a título de ilustração, os gráficos, os manipuladores de pão e os alfaiates, que passaram a se consolidar em sindicatos, ligados à Federação Operária do Amazonas que, por sua vez, estava ligada à COB. Certamente que essas ações de Tércio Miranda geraram disputas em torno de se obter o controle (corpo administrativo/cargos de direção e/ou comissões) das organizações operárias locais. É possível evidenciar tais disputas quando da criação da Federação Marítima no Amazonas:

Os marítimos já têm a sua Federação organizada, abrangendo todos os seus ramos, isto é, todos os seus elementos de trabalho. Moços, marinheiros, criados da copa, taifeiros, maquinistas, pilotos, práticos, foguistas, e enfim, comandantes, todos unidos fundaram a sua federação, que em breve colherá seguramente grandes frutos, dada a boa orientação com que se vêm mantendo.

Apesar de certos empecilhos, criados por indivíduos que não têm a menor noção da causa social-operária, a Federação Marítima é um fato, graças, como acima dissemos, a alguns denominados camaradas, que souberam impor-se, escorraçando de seu seio os elementos intrusos. ${ }^{43}$

Assumir o corpo administrativo e a direção de uma organização operária eram passos fundamentais para organizar a luta dos trabalhadores na perspectiva do sindicalismo revolucionário. As disputas se estendiam do mesmo modo para outras ações direcionadas aos trabalhadores, como na questão da educação. Vimos que Tércio Miranda montou uma escola e uma biblioteca em sua própria casa com o objetivo de utilizar a educação como instrumento

40 PINHEIRO; HALL, op. cit., p. 43.

41 Como Domingos Batista Guedes, Joaquim Azpilicueta, Antônio Dias Martins, Ananias Linhares da Silva e Leonardo da Silva. Sobre tais lideranças ver: TELES, op. cit., 2018.

42 A Lucta Social, Manaus, ano I, n. 2, $1^{\circ}$ maio 1914.

43 MOVIMENTO local. A Lucta Social, Manaus, ano I, n. 1, 29 mar. 1914. 
de emancipação humana. Entrou em polêmica com Raymundo Alves Tribuzy, presidente da Associação dos Empregados no Comércio do Amazonas, que havia implantado um espaço destinado à instrução educacional dos empregados no comércio. Tércio Miranda reconheceu a importância do espaço, porém criticou a sua finalidade, que era qualificar profissionalmente os trabalhadores, para que pudessem galgar posições mais altas na hierarquia das casas comerciais. No fundo ele estava condenado à colaboração de classes, tão característica dos comerciários desse período.

Assim como Antônio Carvalho no Pará, Tércio Miranda conduziu e orientou algumas greves que eclodiram na capital no ano de $1914,{ }^{44}$ tal como a greve dos gráficos do jornal $O$ Amazonas. Nessa greve, Tércio Miranda, como liderança do Sindicato dos Trabalhadores Gráficos do Amazonas, expediu um boletim informando que era dever de todos "não substituir aqueles que se recusaram a trabalhar sem a satisfação dos seus ordenados". ${ }^{45}$ A greve foi deflagrada em função do atraso de salários, e foi um desastre. Houve demissão em massa. ${ }^{46}$

Seguindo uma das diretrizes traçadas pela COB - não incitar os trabalhadores a se declararem em greve sem ter clareza que ela triunfe ${ }^{47}$-, Tércio Miranda publicou um artigo intitulado "Serenamente", onde tratou de fazer uma análise sobre a greve, não sem reforçar o que havia dito antes dela acontecer:

Já no número anterior de nosso jornal, se disse que a tática seguida, ou por outra, a preparação da greve não foi o que devia ser.

\section{$(\ldots)$}

Todos devem se lembrar, pois não é muito o tempo passado, que desde a fundação do Sindicato dos Trabalhadores Gráficos, quando eu me fazia ouvir, mostrava a necessidade de uma ação consciente para a emancipação, mas nunca me esquecia de dizer que o nosso primeiro trabalho devia ser o levantamento moral da classe. Precisávamos da adesão de toda a classe, que não é grande afinal, para estreitarmos indestrutivelmente os laços da solidariedade, indispensável a nossa vitória. Mais que uma vez, como secretário-geral do Sindicato, eu fiz sentir que a nossa agrupação não podia assumir a responsabilidade de qualquer movimento, por se sentir ainda sem forças. O resultado seria negativo, e os nossos adversários (...) teriam ensejo para apontar a nossa invalidade..$^{48}$

Como podemos certificar, as orientações da COB também se materializaram em assuntos específicos, como as greves. Em síntese, os impactos da COB na Região Norte, nos anos de 1913 e 1914, foram intensos e significativos. Em 1915, a COB deixou de existir. Em 1920, realizou-se o $3^{\circ}$ Congresso Operário Brasileiro com participação ativa das lideranças operárias do Norte do país. Antônio Carvalho se fez presente. Já Tércio Miranda não estava mais no

44 Um estudo sobre as greves deflagradas em Manaus entre os anos de 1914 a 1918 foi realizado por: ARAÚJO, Moisés Dias de. 0 grito dos trabalhadores: movimento operário, reivindicações e greves na Manaus da Grande Guerra (1914-1918). 2018. Dissertação (mestrado em História) - PPGH, Universidade Federal do Amazonas, Manaus, 2018.

45 GREVE no Amazonas. A Lucta Social, Manaus, ano I, n. 4, 1 set. 1914.

46 Para mais informações acerca dessa greve consultar: ARAÚJO, op. cit., p. 140-147.

47 A Voz do Trabalhador, Rio de Janeiro, 1 jan. 1913.

48 SERENAMENTE. A Lucta Social, Manaus, ano I, n. 6, 1 nov. 1914. 
país. ${ }^{49}$ Não obstante, o Amazonas marcou presença no $3^{\circ}$ Congresso através de outras lideranças, agora socialistas reformistas. Podemos ter noção das conexões estabelecidas nesse congresso observando a imagem abaixo:

\section{IMAGEM 1 - Demonstração gráfica da organização da Comissão Executiva do $3^{\circ}$ Congresso Operário}

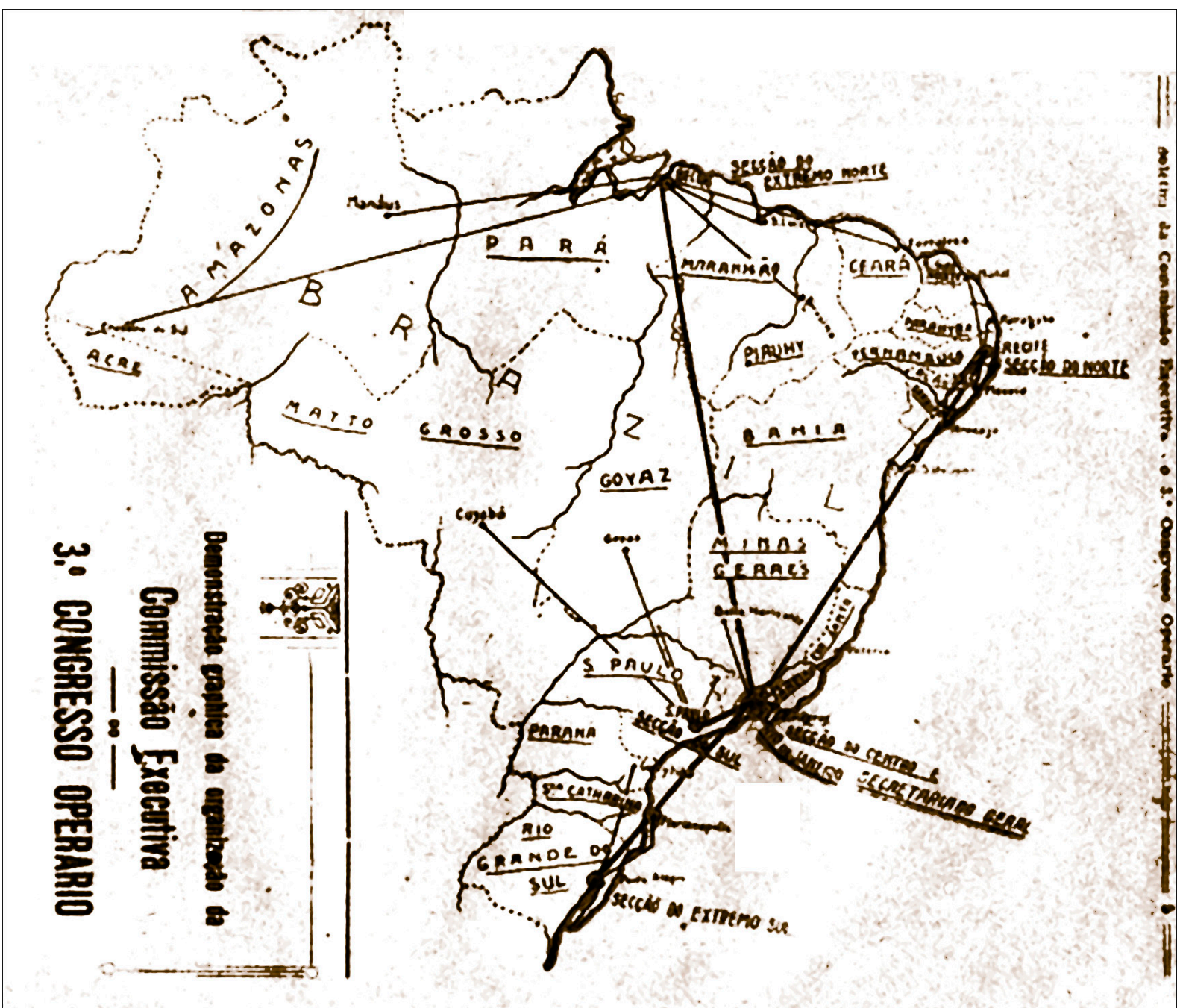

Fonte: Boletim da Comissão Executiva do $3^{\circ}$ Congresso Operário, São Paulo, ano I, n. 1, ago. 1920.

No mapa é possível identificar uma proposta de organização de alcance nacional subdividida em cinco seções: a primeira situada no centro, composta pelos estados do Rio de Janeiro (com sede na cidade do Rio de Janeiro), Espírito Santo e Minas Gerais. Ligada a essa seção está a do sul, agregando os estados de São Paulo (com sede na cidade de São Paulo), Goiás e Mato Grosso, além de duas zonas do Triângulo Mineiro e do sul de Minas; a do extremo sul, formada pelo Rio Grande do Sul (com sede em Porto Alegre), Paraná e Santa Catarina; a do norte, integrada por Pernambuco (com sede em Recife), Rio Grande do Norte, Paraíba, 
Alagoas, Sergipe e Bahia; e, por fim, a do extremo norte, constituída pelo Pará (com sede em Belém), Amazonas, Maranhão, Ceará, Piauí e Acre. ${ }^{50}$ Dessa forma, o Pará e o Amazonas comparecem na seção do extremo norte, firmando-se nessa correlação regional e se inserindo numa articulação mais ampla, por onde os militantes deveriam se mover nacionalmente.

Em Manaus, não foi à toa que as lideranças fundaram um jornal chamado $O$ Extremo Norte (1920). Não foi a esmo, igualmente, que canalizaram esforços para novamente organizar os trabalhadores, mas, nesse momento, sob a perspectiva do socialismo reformista. Fundaram um partido operário e participaram das eleições locais de 1920, pois, como reformistas, acreditavam que no Parlamento, por meio de leis específicas, poderiam melhorar as condições de trabalho e vida dos operários amazonenses. Era já outro momento...

\section{Considerações finais}

NÃO HÁ COMO entender as conexões entre a COB e a Região Norte sem considerar as transformações estruturais pelas quais as duas capitais passaram, sobretudo a integração mundial impulsionada pela economia gomífera, a ampliação do mercado de trabalho e o avanço dos impressos. Do mesmo modo, é fundamental atentar para a trajetória dos nossos dois personagens, Tércio Miranda e Antônio Carvalho, que se deslocaram para a Amazônia e encontraram um terreno fértil para a difusão dos ideais libertários.

Embora, num primeiro momento, entre os anos de 1908 e 1909, em virtude de uma ação limitada ao Rio de Janeiro, a COB pouco ou nada impactou a Região Norte, o momento subsequente (1913-1914) foi de intensos e significativos efeitos sobre a Amazônia, como observamos. E, mesmo no ano de 1920, houve influência sobre as duas capitais. Antônio Carvalho participou do $3^{\circ}$ Congresso Operário Brasileiro, por exemplo. E, em Manaus, agora sob a hegemonia do socialismo reformista, as lideranças locais buscaram incansavelmente organizar os trabalhadores em torno de um Partido Operário e sustentar a publicação do jornal O Extremo Norte (1920). Este momento de 1920 requer investigações, mas, pelos movimentos e ações identificadas, podemos dizer sem receios que os debates que ocorreram no $3^{\circ}$ Congresso - A COB já não existia mais - atingiram novamente a região e, assim como em 1913/1914, fizeram estremecer a floresta tropical.

Recebido em 27/09/2021

Aprovado em 29/10/2021

50 NORMAS de organização da comissão executiva do $3^{\circ}$ Congresso Operário. Boletim da Comissão Executiva do $3^{\circ}$ Congresso Operário, São Paulo, ano I, n. 1, ago. 1920. 